\title{
LESIONS OF JOINTS AND TENDON SHEATHS IN SYSTEMIC LUPUS ERYTHEMATOSUS
}

\author{
BY \\ BRUCE CRUICKSHANK \\ University Department of Pathology, Glasgow Royal Infirmary
}

Joint involvement is recognized clinically as a common feature in systemic lupus erythematosus (SLE). Thus, Ross and Wells (1953), in reviewing the literature, observed that arthralgia or arthritis occurred in 80 per cent. of cases. Harvey, Shulman, Tumulty, Conley, and Schoenrich (1954) and Haserick (1955) recorded incidences of 95 out of 105 and 107 out of 126 cases respectively. Arthritis frequently precedes other symptoms, sometimes by long periods (Dubois, 1953; Harvey and others, 1954; Haserick, 1955). A few authors consider the arthritis to be migratory or transient (Coburn and Moore, 1943), but many comment on the occurrence of changes similar, both clinically and radiographically, to those of rheumatoid arthritis (Slocumb, 1940; Bywaters, 1949; Shearn and Pirofsky, 1952; Friedman, Schwartz, Trubek, and Steinbrocker, 1953; Ross and Wells, 1953; Dubois, 1953; Harvey and others, 1954; Haserick, 1955). Some of these authors regard the rheumatoid type of lesion as unusual (Bywaters, 1949; Haserick, 1955), but others have observed this type of arthritis in over one-quarter of the patients they have studied (Friedman and others, 1953; Ross and Wells, 1953; Dubois, 1953; Harvey and others, 1954). Ankylosis was observed in one patient by Shearn and Pirofsky (1952), and the cases studied by Ross and Wells (1953) included some with rheumatoid lesions of Stage IV (Steinbrocker, Traeger, and Batterman, 1949).

In contrast, little attention has been paid to the histological appearances in the joints. Thus, these lesions are not mentioned in the classical paper by Klemperer, Pollack, and Baehr (1941), although this group of workers describe and illustrate haematoxylin bodies in the synovial tissue in a later article (Klemperer, Gueft, Lee, Leuchtenberger, and Pollister, 1950). Indeed, there appears to be only one article devoted to the joint lesions of SLE (Bennett and Dällenbach, 1951); this describes only the synovial changes and is not readily available outside the United States.

The purpose of the present communication is to describe and illustrate in detail the histological appearances in all components of joints in the disease, and to record, apparently for the first time, the occurrence of tenosynovitis in SLE.

\section{Material and Methods}

Tissue was obtained at autopsy from fourteen joints from ten patients, in all of whom the diagnosis was confirmed histologically. Metacarpo-phalangeal and proximal interphalangeal joints were obtained from the right middle finger from three patients and whole sections were cut in an antero-posterior plane. Synovial tissue was taken from the knee (6), ankle (1), or shoulder (1), and flexor tendons and their sheaths from the palm of seven patients. Three blocks were taken from each specimen of synovial tissue and tendon. The blocks were fixed, decalcified when necessary, and embedded in paraffin. Sections from all specimens were stained with haematoxylin and eosin for histological examination and sections from three joints and three tendons were stained by the periodic acid-Schiff, Feulgen, methyl greenpyronin, picro-Mallory, phosphotungstic acid-haematoxylin, toluidin blue, and Prussian blue methods for histochemical study.

\section{Results \\ Clinical and Radiological Appearances}

All but one of the patients had shown clinical evidence of arthritis. In two patients, pain and swelling of joints was the initial symptom, to be followed in a few weeks by other symptoms, including the characteristic rash. In the other patients, evidence of lesions elsewhere had accompanied or preceded the arthritis. The clinical features were pain and swelling involving several joints, most frequently those of the hands and wrists.

Evidence of permanent damage was seen only 
once, when well-marked ulnar deviation of the fingers, with subluxation of the metacarpophalangeal joints developed late in the course of the disease (Fig. 1). A radiograph taken a year before death shows marked periarticular osteoporosis and narrowing of the joint spaces in the fingers of both hands.

None of the patients showed clinical evidence of tenosynovitis. Steroid therapy had been used in seven patients.

\section{Morbid Anatomy}

Most of the joints showed only minimal changes, such as small effusions and congestion of the synovial tissue. Early pannus was seen on the femoral condyles in two knees and in another knee there was definite acute synovitis. No macroscopic abnof? mality was detected in the tendon sheaths.

\section{Histology}

Joints.-All but one of the fourteen examine showed histological changes, despite the absence of striking macroscopic abnormality.

Synovial Tissue.-Here the most constant and often the most striking feature was the presence of thick layer of brightly eosinophilic, fibrin-lik $\vec{\omega}$ material on or under the surface (Figs 2 and 38 This material merged with the adjacent synoviura

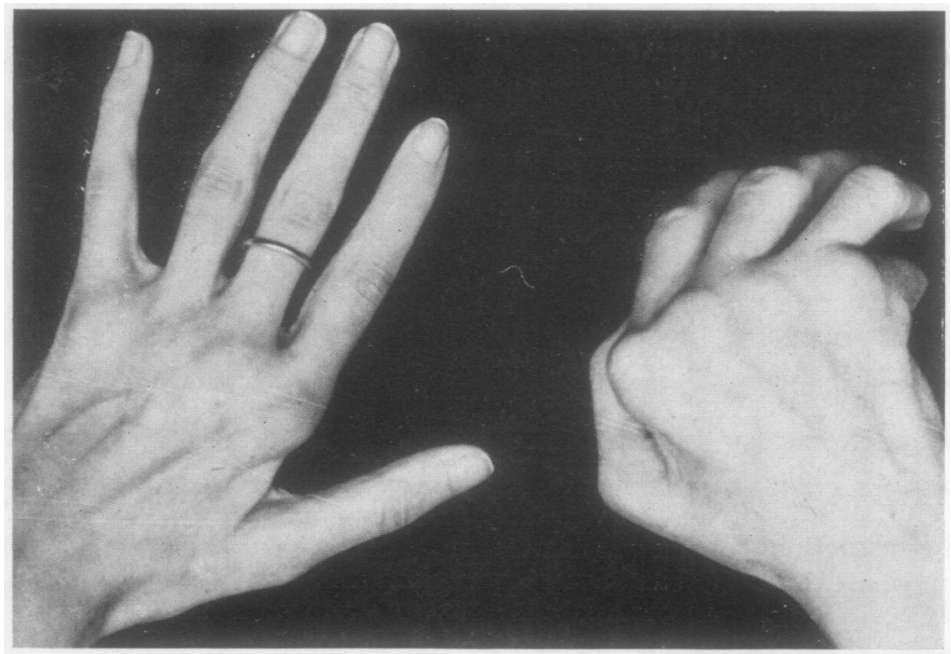

Fig. 1.-Clinical appearance of hands a fe months before death, showing bilateral ulnot deviation and subluxation of right metacarpo phalangeal joints.

Fig. 2.-Knee (same patient as Fig. 1): portions of two villi with thick layer of fibrin-like material on surface. No inflammation, but some fibrosis in core. Phosphotungstic acid-haematoxylin. $\times 75$.

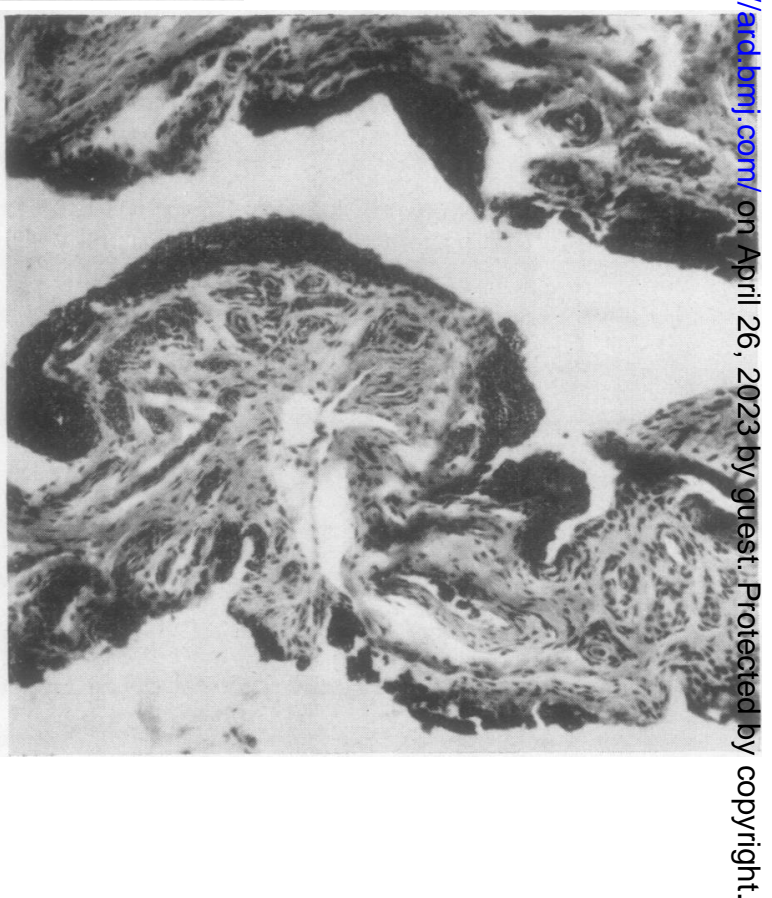


Fig. 3.-Knee: complete loss of synovial lining cells, with layer of fibrin-like material on surface. Oedema of underlying tissue without cellular infiltration. Haematoxylin and eosin. $\times 55$.

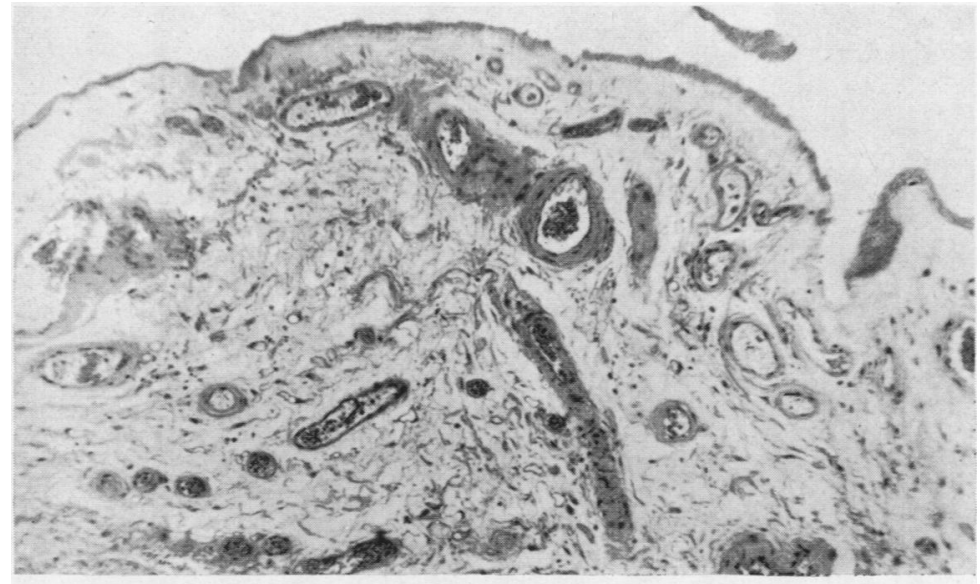

and frequently contained pyknotic nuclei. It was seen in eleven joints.

The main change in the synovial cells was a diminution in their number (seven patients).

These two changes were frequently combined so that the eosinophilic material lay directly on the sub-synovial tissue. Sometimes they involved all the tissue examined (Fig. 3), but in three joints they alternated with regions of normal structure or of moderate hyperplasia of the synovial cells (Fig. 2). Frank necrosis of synovial cells was seen in the knee and proximal interphalangeal joint of one patient.

Haematoxylin bodies, distinct from pyknotic nuclei, were found in eleven joints. They were most common among the synovial cell nuclei (Fig. 4), but could also be seen deeper in the tissue. In one joint they were found only in the latter situation. It was sometimes necessary to search several highpower fields before the bodies were seen, but in one knee they were present in all fields of the surface layer examined (Fig. 4).

Inflammation was slight or absent. Slight to moderate infiltration with lymphocytes and plasma cells was the most severe change seen (Fig. 5, overleaf).

In two joints, oedema was the only feature. It was common to find plentiful eosinophilic material with little or no inflammatory change. Polymorphs were seen only once, in small numbers. Macrophages and fibroblasts were not seen. Despite this, six joints showed slight or moderate fibrosis of the deeper tissues (Fig. 6, overleaf).

Vascular lesions were not marked, except in one patient, who had a combination of the characteristic visceral lesions of SLE and widespread polyarteritis nodosa. Lesions of both conditions occurred in the knee examined and have been illustrated in a previous article (Cruickshank, 1952). Minor lesions,

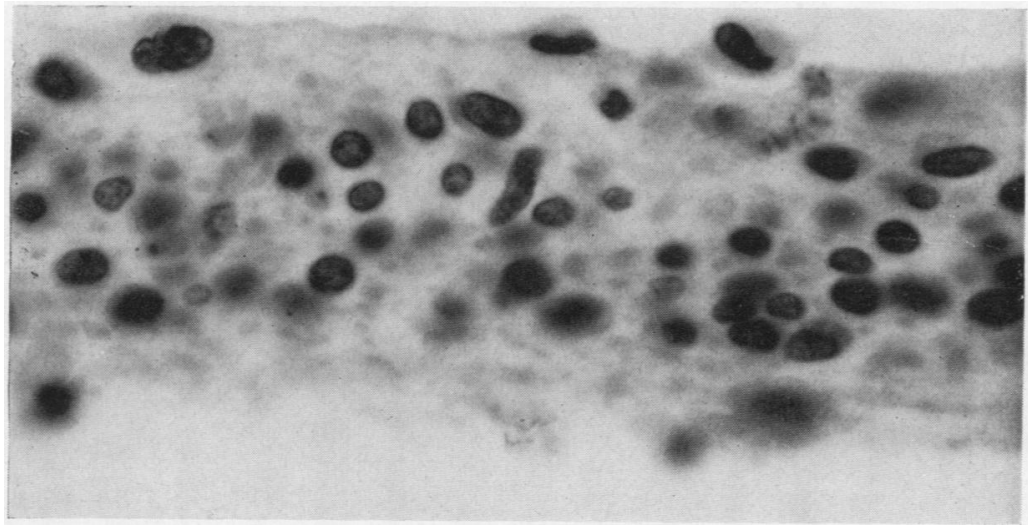

Fig. 4.-Knee: portion of a small villus, showing many small haematoxylin bodies among nuclei of synovial cells. Haematoxylin and eosin. $\times 650$. 

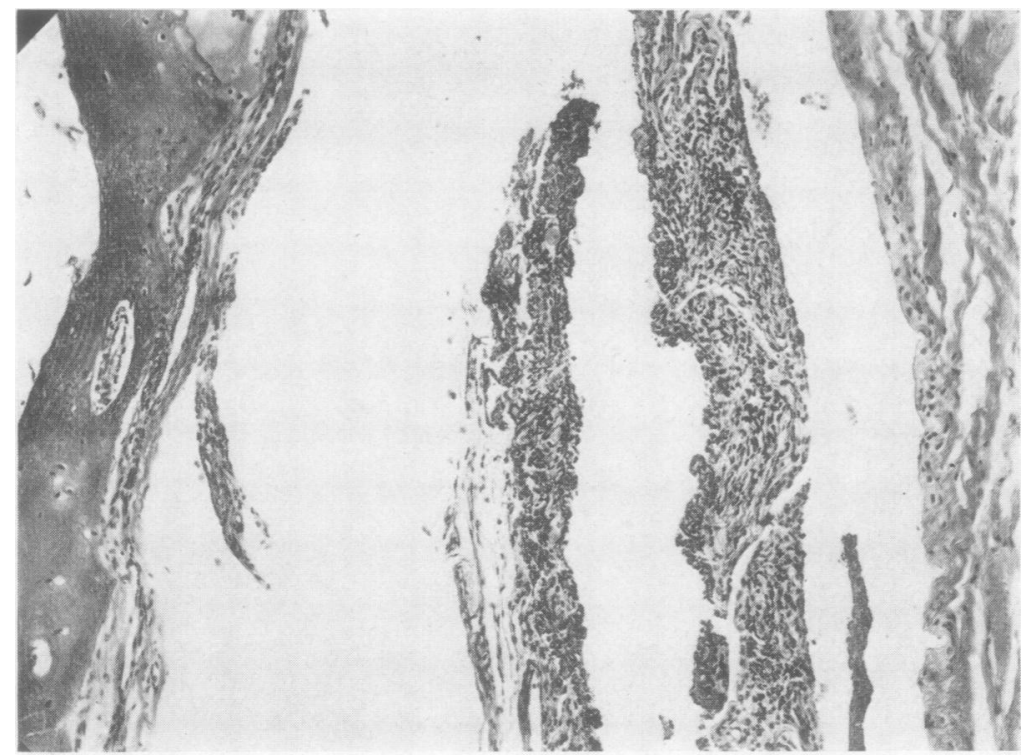

Fig. 5-Metacarpo-phalangeal joint. slight hyperplasia of synovial cells apa infiltration with lymphocytes afid plasma cells. Haematoxylin and eosim. $\times 100$.

Fig. 6.-Knee (same patient as Fig. 1): diminue tion in number of synovial cells, fibrin-like material in upper villus, and fibrosis of larger villus. Haematoxylin and eosin. $\times 90$.

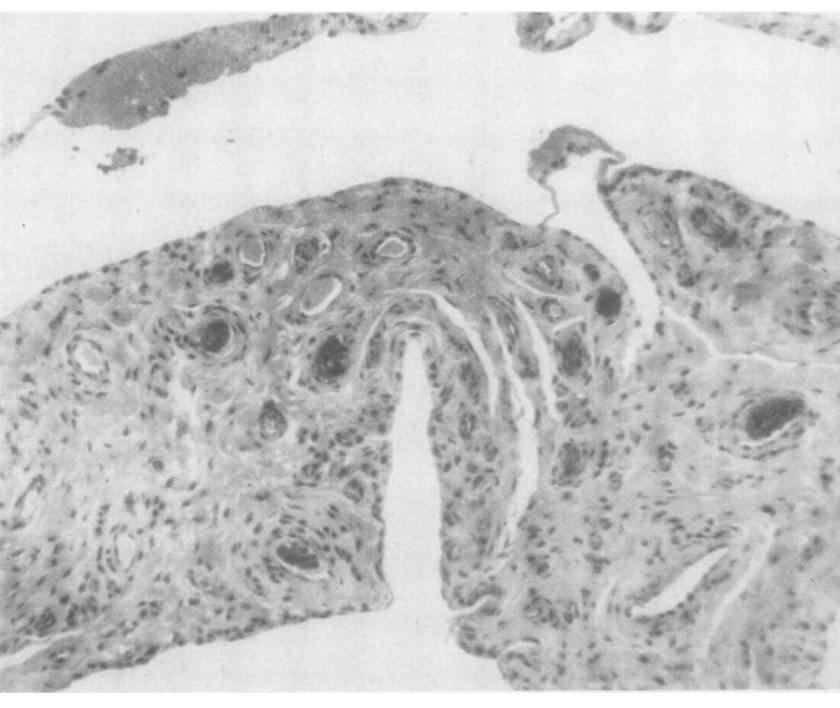

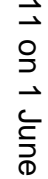

which occurred in four other patients, included intimal fibrosis of small arteries or veins. Widespread organizing venous thrombosis was seen in the knee of one patient (Fig. 7, opposite). Recent haemorrhage was seen in this joint, and haemosiderin was seen in two other joints.

Histochemical studies were disappointing, for much of the tissue had been fixed in Helly's fluid, so that the Feulgen and methyl green-pyronin methods were unsuccessful. The eosinophilic material on and under the surface was Schiff- positive, bright red in the picro-Mallory method and deep violet with phosphotungstic acid-haematoz xylin (Fig. 2). It was not metachromatic with toluidine blue.

Articular Cartilage.-Damage was seen in five the six finger joints. In three of these joints, then was marginal erosion with a thin layer of granulation tissue on the surface of the cartilage or on the su亩chondral bone plate where the cartilage had disappeared (Fig. 8, opposite). Minimal inflammatiơ 


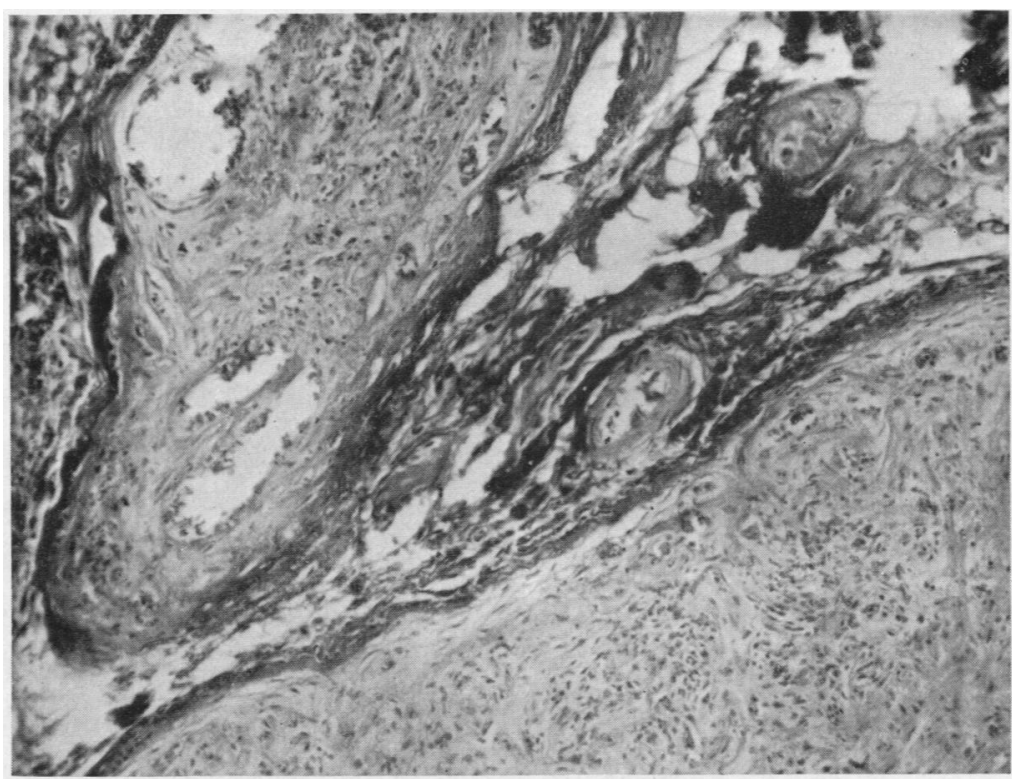

Fig. 7.-Knee (same patient as Fig. 3): two large veins completely occluded by fibrous tissue, with recanalization of one. Fibrosis of intervening venules. van Gieson. $\times 150$.

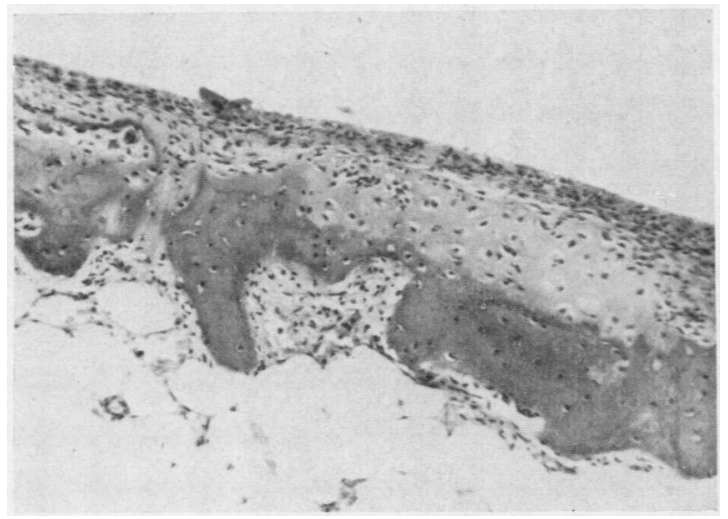

Fig. 8.-Proximal interphalangeal joint (from right hand in Fig. 1): marginal region showing loss of cartilage, thin layer of pannus on surface, and minimal involvement of underlying bone.

Haematoxylin and eosin. $\times 70$.

was seen in the immediately adjacent bone. The appearances were similar to, but less severe than, those of rheumatoid arthritis. The remaining two joints were from the hand shown in Fig. 1. Here, there was extensive loss of cartilage, sometimes with a thick layer of granulation tissue on the exposed bone (Fig. 9). The subchondral plate was thickened in places and inflammatory foci in the bone were more obvious.

Tendon-sheath Involvement.-This was seen in six of the seven patients investigated.

Fibrin-like material was present on or beneath the

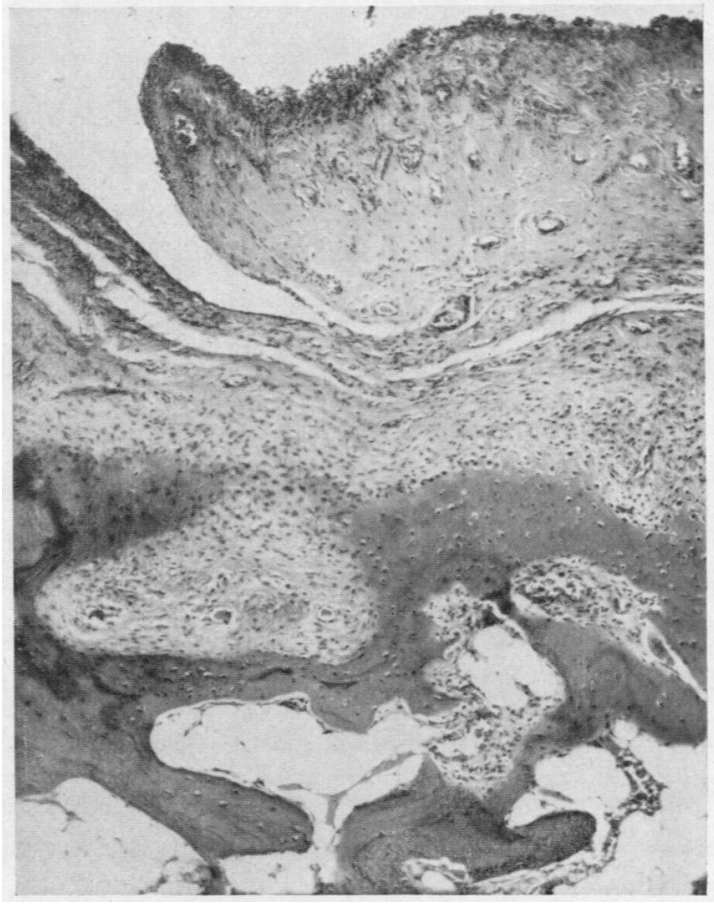

Fig. 9.-Metacarpo-phalangeal joint (from right hand in Fig. 1): central region showing replacement of entire depth of articular cartilage by fibrous pannus.

Haematoxylin and eosin. $\times 55$. 
surface in all six patients, often associated with a diminution in the number of synovial cells (Fig. 10). Frank necrosis was not seen.

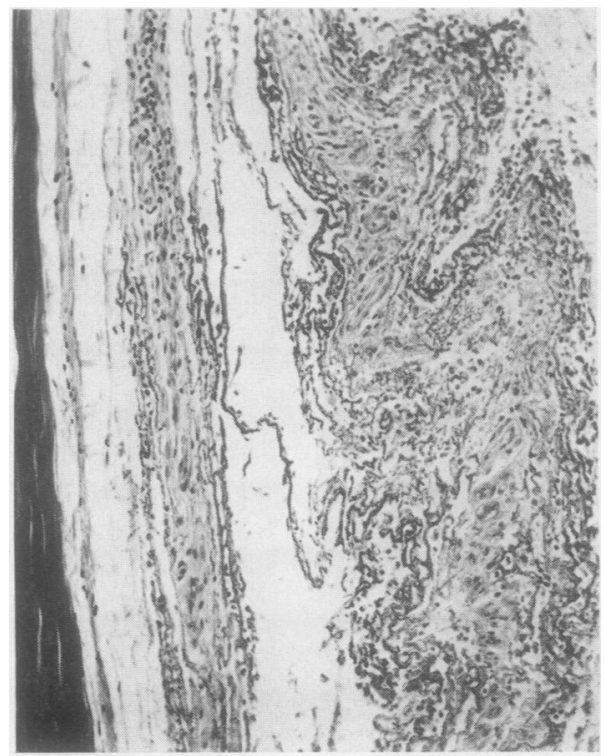

Fig. 10.-Tendon sheath: marked deposition of fibrin-like material on surface of both layers of sheath, with loss of synovial cells and minimal cellular infiltration. Haematoxylin and eosin. $\times 100$

Haematoxylin bodies were seen in five patients and were distributed among the synovial cell nuclei on the surface and the inflammatory cells beneath the surface (Fig. 11).
Inflammation was more marked than in the joints. In one patient it was particularly severe acute in type, and associated with degeneration and necrosis of many of the cells of the exudate. The? tendon was involved along with its sheath and there was marked disruption of the collagen fibres: (Fig. 12). The remaining patients showed an

Fig. 12.-Tendon sheath: severe acute inflammation involving sheath and adjacent tendon, with necrosis of exudate and tendon. Haematoxylin and eosin. $\times 150$.

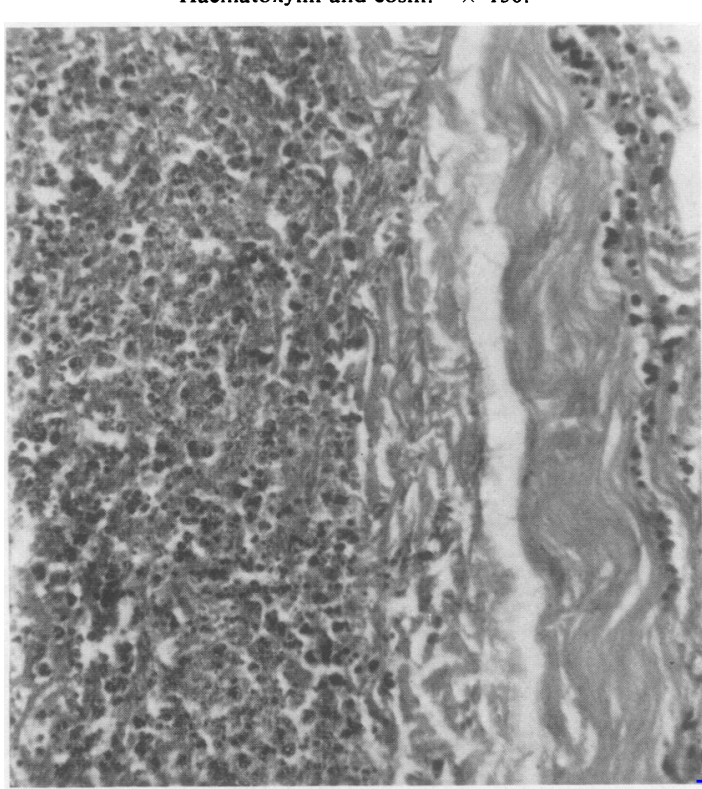

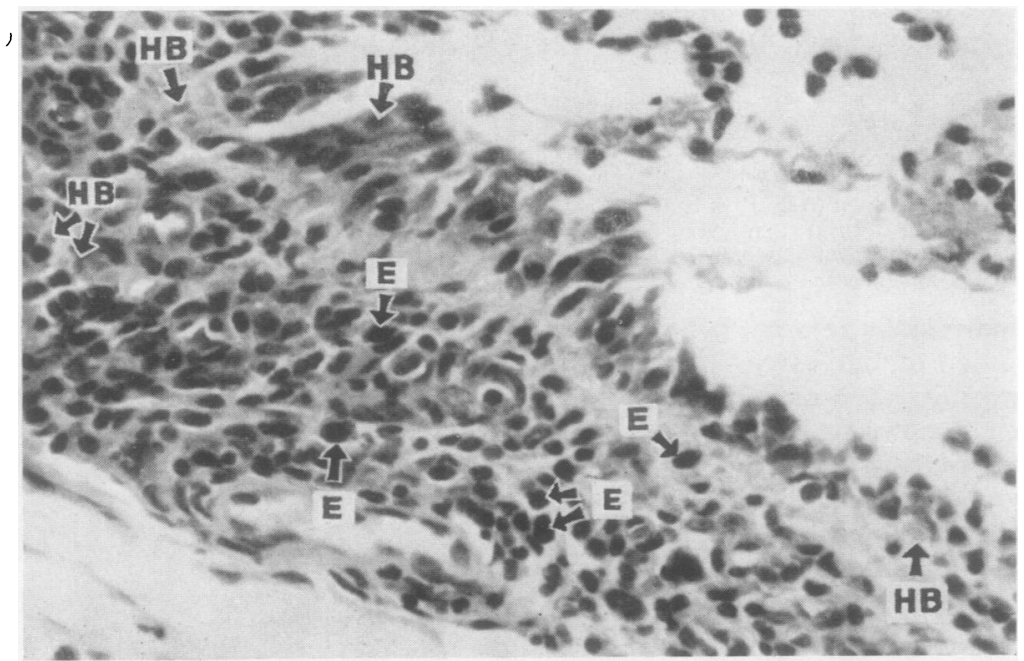

Fig. 11.-Tendon sheath (same patient as Fig. 1): infiltration with lymphocytes, plasma cells, and eosinophils (E). Haematoxylin bodies (HB) scattered among healthy nuclei. Haematoxylin and eosin. $\times 380$ 
exudate of lymphocytes and plasma cells, with occasional polymorphs and eosinophils (Figs 11 and 13).

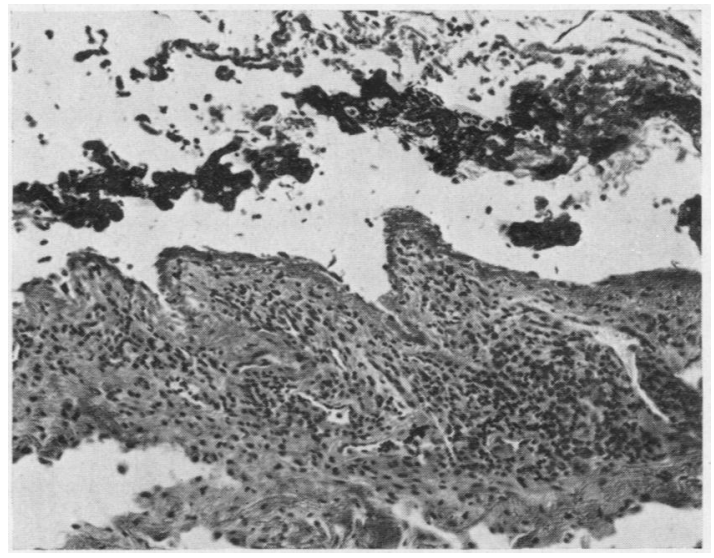

Fig. 13.-Tendon sheath (same patient as Fig. 5): fibrin-like material in space between layers of sheath and on surface of one layer. Loss of synovial cells and marked cellular infiltration.

$$
\text { Haematoxylin and eosin. } \times 100 \text {. }
$$

Slight fibrosis was seen in four patients and intimal fibrosis of arterioles in two. An unusual appearance was seen in one case, the tendon sheath being nearly $2 \mathrm{~mm}$. thick at one place. Here the space between the tendon and its sheath was obliterated by a nodule of large mesenchymal cells of synovial type, infiltrated with lymphocytes and plasma cells. No degeneration was seen within this nodule, nor was there any fibrosis (Fig. 14).
Histochemical studies confirmed the findings in the joints. In addition the haematoxylin bodies in two patients were shown to contain DNA (Feulgenpositive), but not RNA (pyronin-negative). DNA was not identified in the fibrin-like material in these two patients.

\section{Discussion}

These pathological changes show a number of interesting features. The presence of a layer of fibrin-like material on the surface of the synovial tissue appears to be an important feature, for it has been observed previously (Bennett and Dällenbach, 1951; Gold and Gowing, 1953; Ropes and Bauer, 1953). These and other workers (Friedberg, Gross, and Wallach, 1936; Ginzler and Fox, 1940; Bennett and Paul, 1949) have also noted that cellular evidence of inflammation was minimal or moderate. The present study confirms this. These observations suggest that the fibrin-like material may be different from that of an ordinary fibrinous exudate. Indeed, an exudate of the type in question is not seen in other forms of synovitis. The limited histochemical studies now reported suggest that the fibrin-like material is similar to the "fibrinoid" encountered in other situations in the disease (Klemperer and others, 1941). This has been shown to contain not only fibrin (Gitlin, Craig, and Janeway, 1957), but also acid mucopolysaccharide (Altshuler and Angevine, 1949), DNA (Klemperer and others, 1950), non-histone protein (Gueft and

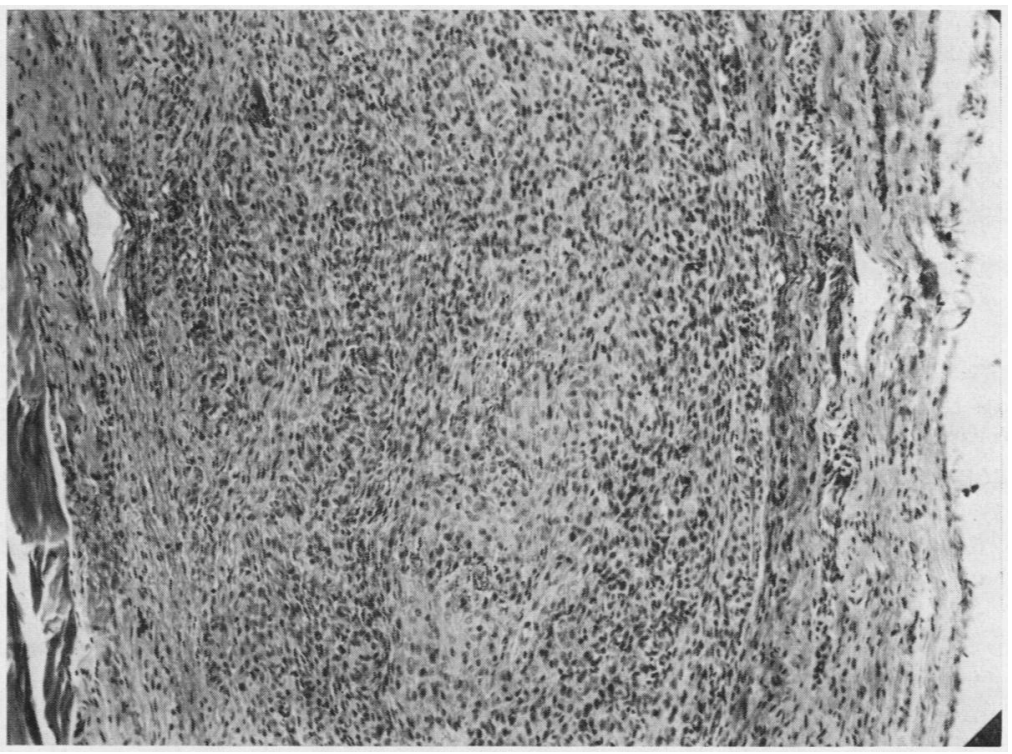

Fig. 14.-Tendon sheath (same patient as Fig. 5): focal proliferation of large mesenchymal cells and infiltration with lymphocytes and plasma cells. Haematoxylin and eosin. $\times 100$. 
Laufer, 1954), and gamma-globulin (Vazquez and Dixon, 1957, 1958). Thus the eosinophilic material on or in the synovial tissue may well be an integral part of the disease process.

Another feature which was observed in the majority of the specimens was the diminution in the number of synovial cells. Here again, the lesions of SLE differ from those of the other chronic arthritides in which proliferation of the synovial cells occurs. Bennett and Dällenbach (1951) noted this feature, and it is implied by the absence of hypertrophy of the synovial villi which is noted in all the reports, except that of Tremaine (1934). Hyperplasia of the synovial cells was observed by Zevely, French, Mikkelsen, and Duff (1956) in punch-biopsy specimens from three patients, but previous experience (Cruickshank, 1952) suggests that the small pieces of tissue obtained by this technique are not truly representative of the changes in the tissue in a chronic arthritis. The loss of synovial cells may well be due to the action of the LE factor, for haematoxylin bodies were found in most of the specimens. They are such an integral part of the pathology of the disease that it is surprising that they seem to have been observed in the synovial tissue by only two previous groups of workers (Klemperer and others, 1950; Ropes and Bauer, 1953).

Although the inflammatory changes were slight, granulation tissue (pannus) was found and was associated with loss of articular cartilage. This was usually confined to the marginal zone of the cartilage so that gross disorganization of the joints was unusual. Nevertheless, extensive loss of cartilage was seen in one patient, and had resulted in an appearance indistinguishable clinically from that of classical rheumatoid arthritis. It should be noted, however, that involvement of the subchondral bone, which is common in rheumatoid arthritis, was unusual and mild in the present material and that no evidence of adhesions or fibrous ankylosis was seen in SLE.

Vascular changes were considered to be an important feature of the synovial lesions of SLE by Lowman (1951), who described acute oedematous phlebitis in five patients, and by Ropes and Bauer (1953), who found necrotizing inflammation of small vessels with frequent fibrin thrombi in six patients. Neither of these changes was observed in the present study, but significant vascular involvement was seen twice. One patient, who had widespread polyarteritis as well as SLE, showed arterial lesions of the former in the knee. The arteritis could not be ascribed to the effect of therapy, for neither corticosteroids nor ACTH had been used, and there was no evidence of any toxic reaction to those drugs which had been administered. A secone patient had widespread organizing venous throm: bosis associated with marked deposition of eosinos philic material on the surface and severe oedemao but little or no cellular reaction. It seems unlikelyo that the thrombosis was the cause of the fibrin-like exudate, though it may well have been responsible for the oedema.

Tenosynovitis does not appear to have been described before in SLE, either clinically or patho? logically. Although no clinical evidence of the $\vec{e}$ changes in the present patients was obtained, i⿱ may be that other features during the terminat illnesses overshadowed any symptoms or signs. referable to the tendon sheaths. The amount o甲 fibrin-like material present in some of the tissue examined suggests that crepitus should be detectable clinically.

Most of the pathological features observed in this study are non-specific. However, it must be cone cluded that the combination of changes is diagnostio of SLE, for they do not occur together in any other known disease. The absence of Aschoff nodulese rheumatoid granulomata, or massive lymphocyte $\rho$ plasma cell infiltration further distinguish SLE frorg rheumatic fever and active rheumatoid arthritis Confusion might arise between mild or inactiv rheumatoid arthritis and SLE with marked loss of cartilage, but the absence of fibrous adhesions an 8 the presence of the surface layer of fibrin-lik material in SLE, even when severe damage has occurred, should serve to differentiate the two conditions. The observation of haematoxylit bodies is the final proof of the diagnosis, foc the histological and cytochemical properties these bodies are specific (Klemperer and others, 1950; Gueft and Laufer, 1954; Godmar, Deitch, and Klemperer, 1958).

\section{Summary}

Tissue was examined from fourteen joints frorf ten patients, and from palmar tendon sheaths from seven patients suffering from systemic lupus eryth\&్్ㅛ matosus.

The main lesion found in the joints was the deposition of fibrin-like material on the surface or within the synovial tissue, associated with loss of synovial cells and haematoxylin bodies. Cellular evidence of inflammation was slight. Replacemen of articular cartilage with granulation tissue occurre but adhesions and ankylosis were not seen.

Changes in the tendon sheaths were similar to 
those in the synovial tissue of the joints, though cellular infiltration was more striking.

The changes observed are individually nonspecific, but collectively they differ from those of other arthritides and are diagnostic.

\section{REFERENCES}

Altshuler, C. H., and Angevine, D. M. (1949). Amer. J. Path., 25, 1061

Bennett, G. A., and Dällenbach, F. D. (1951). Mil. Surg., 109, 531. , and Paul, J. T. (1949). Amer. J. clin. Path., 19, 177.

Bywaters, E. G. L. (1949). Ann. rheum. Dis., 8, i.

Coburn, A. F., and Moore, D. H. (1943). Bull. Johns Hopk. Hosp. 73, 196.'

Cruickshank, B. (1952). Ann. rheum. Dis., 11, 137.

Dubois, E. L. (1953). Ann. intern. Med., 38, 1265.

Friedberg, C. K., Gross, L., and Wallach, K. (1936). Arch. intern. Med., 58, 662.

Friedman, H. H., Schwartz, S., Trubek, M., and Steinbrocker, O. (1953). Ann. intern. Med., 38, 732 .

Ginzler, A. M., and Fox, T. T. (1940). Arch. intern. Med., 65, 26. Gitlin, D., Craig, J. M., and Janeway, C. A. (1957). Amer. J. Path., 33, 55.

Godman, G. C., Deitch, A. D., and Klemperer, P. (1958). Ibid., 34,1

Gold, S. C., and Gowing, N F. C. (1953). Quart. J. Med., 22, 457.

Gueft, B., and Laufer, A. (1954). A.M.A. Arch. Path., 57, 201.

Harvey, A. M. Shulman, L. E., Tumulty, P. A., Conley, C. L., and Schoenrich, E. H. (1954). Medicine (Baltimore), 33, 291.

Haserick, J. R. (1955). J. chron. Dis., 1, 317.

Klemperer, P., Gueft, B., Lee, S. L., Leuchtenberger, C., and Pollister, A. W. (1950). Arch. Path. (Chicago), 49, 503 .

-, Pollack, A. D., and Baehr, G. (1941). Ibid., 32, 569.

Lowman, E. W. (1951). Ann. rheum. Dis., 10, 16.

Ropes, M. W.. and Bauer, W. (1953). "Synovial Fluid Changes in Joint Disease." Harvard University Press, Cambridge, Mass.

Ross, S. W., and Wells, B. B. (1953). Amer. J. clin. Path., 23, 139.

Shearn, M. A., and Pirofsky, B. (1952). Arch. intern. Med., 90, 790

Slocumb, C. H. (1940). Proc. Mayo Clin., 15, 683.

Steinbrocker, O., Traeger, C. H., and Batterman, R. C. (1949). J. Amer. med. Ass., 140, 659.

Tremaine, M. J. (1934). New Engl. J. Med., 211, 754.

Vazquez, J. J., and Dixon, F. J. (1957). Lab. Invest., 6, 205.

Vazquez, J. (1958). A.M.A. Arch. Path., 66, 504.

Zevely, H. A., French, A. J., Mikkelsen, W. M., and Duff, I. F. (1956). Amer. J. Med., 20, 510.
Lésions des articulations et des gaines tendineuses dans le lupus érythémateux généralisé

RÉSUMÉ

On examina les tissus provenant de 14 articulations de 10 malades et de gaines tendineuses palmaires de 7 malades atteints de lupus érythémateux généralisé.

La lésion principale trouvée dans les articulations fut le dépôt d'une substance ressemblant à la fibrine, à la surface ou dans le tissu synovial, associé à une perte de cellules synoviales et de corpuscules colorés par l'hématoxyline. Il y eut peu de signes d'inflammation cellulaire. Le remplacement du cartilage articulaire par le tissu de granulation fut noté, mais on n'observa pas d'adhésions ou d'ankylose.

Les lésions des gaines tendineuses furent similaires à celles du tissu synovial des articulations, mais l'infiltration cellulaire fut plus accentuée.

Les lésions observés ne sont pas spécifiques en soimême, mais leur ensemble les distingue des autres arthritides et les rend diagnostiques.

Lesiones de las articulaciones $\mathbf{y}$ de las vainas tendinosas en el lupus eritematoso generalizado

\section{SUMARIO}

Se examinaron los tejidos procedentes de 14 articulaciones de 10 enfermos y de vainas tendinosas palmares de 7 enfermos con lupus eritematoso generalizado.

La lesión principal encontrada en las articulaciones fué el depósito de una substancia de tipo de fibrina, superficial o dentro del tejido sinovial, asociado a la pérdida de células sinoviales y de cuerpos a hematoxilina. Hubo pocos signos de inflamación celular. Se notó la reposición del cartilago articular por un tejido de granulación, pero no se vieron adhesiones o anquilosis.

Las lesiones de las vainas tendinosas fueron similares a las del tejido sinovial, pero la infiltración celular fué más acentuada.

Las lesiones observadas no son específicas en si mismo, pero colectivamente difieren de otros artritides y son diagnósticas. 